\title{
The continuous casting technology of the aluminum rod assigned for the wire for electrical purposes
}

\author{
Knych Tadeusz ${ }^{1,}$, Uliasz Piotr $^{1, b}$, Piwowarska Marzena ${ }^{1, c}$ \\ ${ }^{1}$ AGH University of Science and Technology, Department of Non-ferrous Metals, \\ Al. Mickiewicza 30, 30-059 Kraków, Poland \\ atknych@agh.edu.pl, bpuliasz@agh.edu.pl, marzenap@agh.edu.pl
}

Keywords: continuous casting, aluminium rod, aluminium wire, EN AW 1370

\begin{abstract}
New technologies of the production of the aluminium charge assigned for drawing, including the tests on the process of continuous casting (CC). This type of technology, which includes the casting of copper and zinc, is widely spread in the world (trademarks: Upcast, Rautomead and Vertic). Yet, there is a lack of experience in the production and reproduction of the cast wires made of aluminium and its alloys assigned for electrical purposes. That is why the authors of the work aimed at investigating the casting process of the aluminium wires obtained with the technology of continuous casting.
\end{abstract}

\section{Introduction}

The tendency for replacing copper products with aluminium ones, present in the cable industry in the recent years, is mainly connected with the high cost of copper and, in the case of the motor industry, with the aim at lowering the mass of the vehicle. The group of new applications of aluminium wires includes flexible wires class 5 and 6 , used as motor cables and enameled conductors for engine winding. This type of new applications require the wires with the diameters up to $0,2 \mathrm{~mm}$ [1]. This means the need for the search of new materials with the aluminium basis, characterizing in high deformability in the drawing process, with a simultaneous retaining of the required final mechanical and electrical properties of the wires. The basic practical limitation for the cable industry is - the possible to acquire - border diameter of the wires made from the traditionally applied aluminium, which is produced in the line of continuous casting and rolling (CCR), and also the aluminium's natural tendency for recovery, which makes difficult the process of crystallization and creates the risk of a diversification of the properties of the wire rod during the annealing recrystallizing into the temper $O$ [2]. That is why there is a justifiable need for tests on the production technologies of the material assigned for deep drawing. The concept of a new production method for a charge material assigned for the drawing process, presented in this work, aims at the development of a technology of continuous casting of aluminium wires with the required diameter, and next its direct drawing into wires assigned for the electrical purposes. In our assumptions, the casting technology for aluminium wires refers to the continuous casting process for copper and its alloys, developed by Upcast and Rautomead, as well as for zinc, in the Vertic technology.

The article presents the results of the laboratory tests on the process of reproduction of the cast aluminium wires class EN AW 1370, produced in the laboratory line of continuous casting, located at the Non-Ferrous Metal Department of the Academy of Mining and Metallurgy in Kraków.

\section{Laboratory station}

The test were performed with the use of the cast aluminium rods obtained at the laboratory station assigned for the process of continuous horizontal casting of non-ferrous metals. The station consisted of a casting furnace, equipped with a crystallizer system with primary and secondary cooling, as well as a drawing system $[3,4]$. The whole work cycle can be divided into the following casting stages: the period of drawing the solidified metal by rolls, the rest period of the drawing rolls, aiming at transferring a new portion of liquid to the front of recrystallization, and the period of withdrawing the rod, which prevents the cast from sticking to the walls of the crystallizer. By the selection of time relations for these three stages, we obtained different structures and qualities of the cast's surface. 


\section{Material for test}

The material selected for the tests was an aluminium rod class EN AW 1370 [2] produced in the line CCR. With the aim at retaining a uniform chemical composition, the material was divided into two parts: one was melted and cast in the laboratory casting line, and the other underwent the process of industrial annealing into the temper $\mathrm{O}$. The wire rod was annealed in a $2 \mathrm{~m}$ long pipe furnace, at $560^{\circ} \mathrm{C}$ and the annealing time was $36 \mathrm{~h}$. This approach reduced the influence of the chemical composition of aluminium on the properties of the obtained materials. The chemical composition of the examined materials is included in Table 1

Table 1. Chemical composition of the tested materials

\begin{tabular}{cccccccccc}
\hline \multicolumn{10}{c}{ Chemical composition, [\% mas.] } \\
\hline $\mathbf{A l}$ & $\mathbf{F e}$ & $\mathbf{S i}$ & $\mathbf{C u}$ & $\mathbf{Z n}$ & $\mathbf{T i}$ & $\mathbf{V}$ & $\mathbf{C r}$ & $\mathbf{M n}$ & $\mathbf{M g}$ \\
$\mathbf{9 9 , 8 2}$ & 0,102 & 0,045 & 0,003 & 0,011 & 0,000 & 0,000 & 0,000 & 0,002 & 0,002 \\
\hline
\end{tabular}

After melting the charge in an induction furnace and heating the metal up to $850^{\circ} \mathrm{C}$, the casting process was started, and it included the casting of three sections of the test material with the diameter of $14 \mathrm{~mm}$. The casting process was conducted with the drawing rate of $10 \mathrm{~mm} / \mathrm{s}$, followed by a 5 second rest. During the casting process, the withdrawing movement of the cast wire was not performed. The parameter which underwent a change was the feed, that is the amount of the recrystallized material which was drawn during the forward movement of the drawing system. Three types of feeds were applied: the first $-3 \mathrm{~mm}$, the second $-6 \mathrm{~mm}$ and the third $-12 \mathrm{~mm}$. The casting process involved the application of primary cooling with the water flow of $1,5 \mathrm{l} / \mathrm{min}$, as well as secondary cooling equaling $0,4 \mathrm{l} / \mathrm{min}$, which set the temperature of the cast rod at the output of the crystallizer to about $150^{\circ} \mathrm{C}$.

\section{Test results}

The material produced at the laboratory station for continuous horizontal casting underwent tests on the electrical conductivity and density, as well as macro-structural observations and mechanical tests, aimed at the characterization of the initial properties of the cast material. The measurement of the electrical conductivity was performed with the use of the apparatus by Sigmatest Foerster, the mechanical properties were examined on the testing machine by Zwick, and the density of the cast was determined with the application of the laboratory set by Mettler Toledo. The macro-structure of the cast samples was revealed with the Tucker reagent. Their image is presented in Fig. 1. It should be noted that the materials after the process of casting characterize in the typical casting structure, which consists of grains shaped by the given selection of the crystallization conditions.
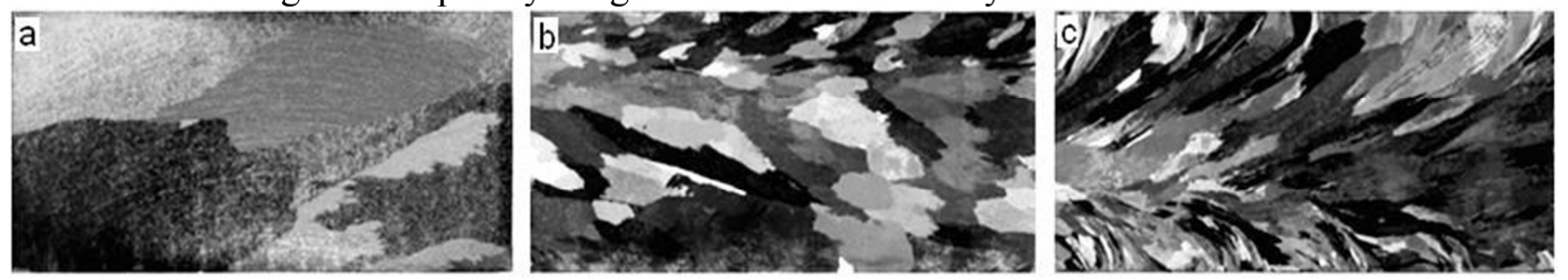

Fig. 1. Structure of casting materials: a) feed $3 \mathrm{~mm}$, b) feed $6 \mathrm{~mm}, \mathrm{c}$ ) feed $12 \mathrm{~mm}$.

The analysis of the macro-structure was performed with the use of the secant method [6]. On its basis, the amount of grains on the longitudinal cross-section of the cast rods was determined (Fig. 1). To that end, on the images of the macro-structure, four parallel lines were plotted, placed perpendicularly to the casting direction. Next, according to the directives in the standard, we determined the amount of grains which had been crossed by the particular lines, and that was the basis for establishing the mean amount of grains crossed at the length of $1 \mathrm{~mm}$, as well as the mean amount of grains at the cross-section of the cast rods (diameter $\varnothing 14 \mathrm{~mm}$ ). The detailed results of the measurements of the amount of grains at the cross-section of the cast, depending on the casting parameter, are presented in Table 2 
Table 2. Analysis of macrostructure of tested samples

\begin{tabular}{cccccc}
\hline Samples & $\begin{array}{c}\text { Feed, } \\
{[\mathrm{mm}]}\end{array}$ & $\begin{array}{c}\text { Length of } \\
\text { measuring line, } \\
{[\mathrm{mm}]}\end{array}$ & $\begin{array}{c}\text { Amount of } \\
\text { crossed } \\
\text { grains }\end{array}$ & $\begin{array}{c}\text { Mean amount of } \\
\text { grains crossed at } \\
1 \mathrm{~mm} \text { length, } \\
{[1 / \mathrm{mm}]}\end{array}$ & $\begin{array}{c}\text { Mean amount of } \\
\text { grains at rod } \\
\text { cross-section }\end{array}$ \\
\hline Cast No. 1 & 3 & 55,04 & 38 & 0,69 & 9,6 \\
Cast No. 2 & 6 & 55,14 & 111 & 2,01 & 28,0 \\
Cast No. 3 & 12 & 54,96 & 136 & 2,47 & 34,6 \\
\hline
\end{tabular}

The tests on the density of the cast point to the fact that the obtained cast characterizes in the proper density level, which proves the lack of casting defects in the form of pores, micro-shrinkages etc. From the cast materials, we selected casts 1 and 2, as well as the wire rod from the CCR line in the temper $\mathrm{O}$, which next underwent the process of drawing into wires, with the total strain equaling about $96 \%$.

Table 3. Properties of tested wires

\begin{tabular}{cccccccc}
\hline Material & $\begin{array}{c}\text { Wire } \\
\text { diameter, } \\
{[\mathrm{mm}]}\end{array}$ & $\begin{array}{c}\text { Wire } \\
\text { strain, } \\
{[\%]}\end{array}$ & $\begin{array}{c}\text { Density, } \\
{\left[\mathrm{g} / \mathrm{cm}^{3}\right]}\end{array}$ & $\begin{array}{c}\text { YS, } \\
{[\mathrm{MPa}]}\end{array}$ & $\begin{array}{c}\text { UTS, } \\
{[\mathrm{MPa}]}\end{array}$ & $\begin{array}{c}\text { Elongation, } \\
{[\%]}\end{array}$ & $\begin{array}{c}\text { Resistivity, } \\
{[\mathrm{n} \Omega \mathrm{m}]}\end{array}$ \\
\hline Cast No. 1 & 3,0 & 96 & 2,697 & 133 & 145 & 3,8 & 27,7 \\
Cast No. 2 & 3,0 & 96 & 2,699 & 139 & 152 & 3,5 & 27,8 \\
$\begin{array}{c}\text { CCR rod - } \\
\text { temper O }\end{array}$ & 1,71 & 96,8 & 2,699 & 152 & 159 & 2,4 & 27,4 \\
\hline
\end{tabular}

In the drawing process of the cast material, no deformability problems were encountered. After each draw, test samples were prepared, which next underwent the test of the uni-axial tension.

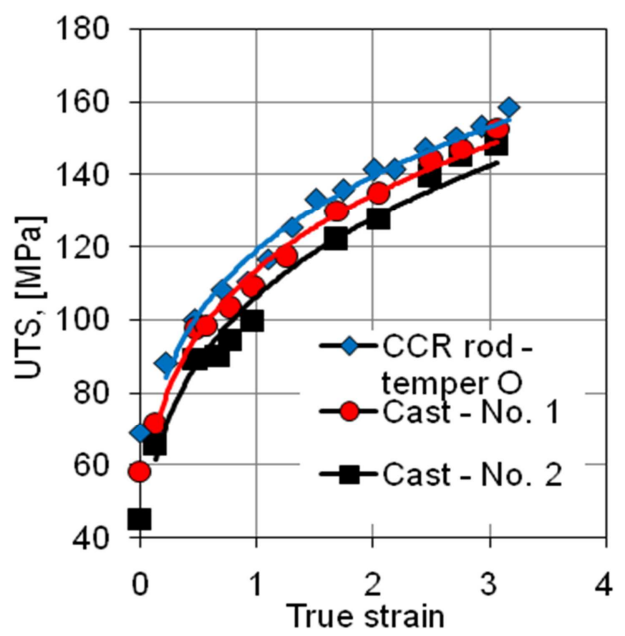

Fig. 2. Technological strengthening curves

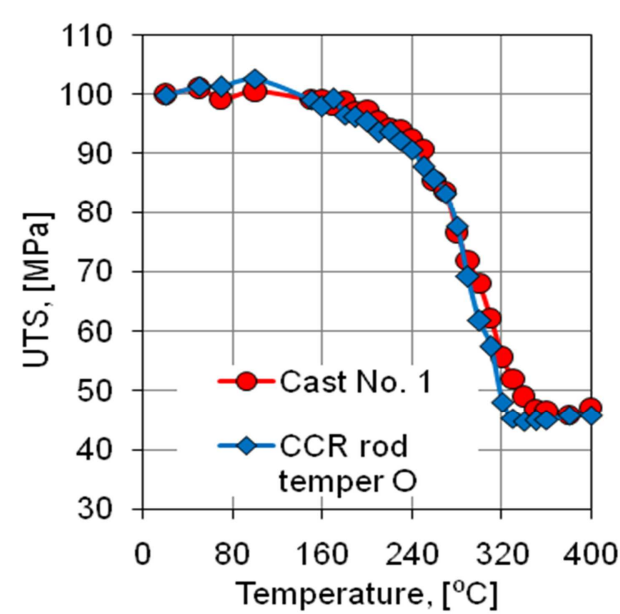

Fig. 3. Softening curves for tested materials

On this basis, the technological strengthening curve of the material in the drawing process was drawn. This curve was created in the relation of the tensile strength in the function of the true strain.

The analysis of the characteristics included in Fig. 2 showed that the strengthening has the same character, independently of the production technology, and the obtained differences result from the diversity in the level of the initial properties of the material. With the strain of about $96 \%$, the strength property level of the examined wires equals about $150 \mathrm{MPa}$. The detailed test results for the final wire properties are presented in Table 3.

The analysis of the test results on the softening curves in a 1 hour test showed that the examined wires with the strain of $93,7 \%$ do not reveal significant differences in the heat resistance. In the case of the wires from the CCR line, in Fig. 3 (blue line), we can see a slight supersaturation at about $100^{\circ} \mathrm{C}$, which is not the case of the cast material. The recrystallization temperature of both materials is similar; however, in the case of the wires from the CCR line, it equals about $330^{\circ} \mathrm{C}$, and in the case of the cast, it is about $20^{\circ} \mathrm{C}$ higher. 


\section{Summary}

On the basis of the analysis of the performed material test on aluminium class EN AW 1370 in the soft state, the following conclusions were drawn:

1. The material produced by the method of casting characterizes in a uniform structure in the length.

2. A change of the parameters of the continuous casting process influences the size of the grains in the obtained cast, and the smaller their feed, the larger the grains, with the long dimension directed along the rod's axis.

3. The strengthening of both materials in the casting process has the same character.

4. The properties of the materials assigned for the drawing process are in both cases similar; however, it should be noted that the cast which exhibits the properties of a soft material does not require the application of an additional thermal sample, which has a significant economical aspect.

5. The softening curves of the wires strained by 93,7\% exhibit the same character of changes; however, in the case of the wires drawn from a material with the cast structure, a slightly higher recrystallization temperature can be observed.

\section{References}

[1] Report of the project: Development of technologies and the production of a new generation of enamelled aluminium wires, UST-AGH, Kraków (2010)

[2] EN 515:1996, Aluminium and aluminium alloys. Wrought products. Temper designations

[3] Knych T., Uliasz P., Piwowarska M., Kwaśniewski P., Kiesiewicz G.: Rudy i Metale Nieżelazne Vol 7 (2010), p. 464-469

[4] Knych T., Uliasz P., Piwowarska M.: Research on technology for continuous casting rods with aluminium for direct drawing, Materials of Conference ProFuturo, Kraków (2010), p. 31-41

[5] EN 573-5:2009, Aluminium and aluminium alloys. Chemical composition and form of wrought products. Codification of standardized wrought products

[6] EN ISO 2624, Copper and copper alloys - Estimation of average grain size 